\title{
A Study of Marketing Techniques and Consumer Protection in the Regulatory Framework of the European Union
}

\author{
Ana Komljenovic and Brana Komljenovic
}

\begin{abstract}
The European Union has decided to put an end to the false advertising, misleading consumers by promising them better health and appearance. According to new rule of European Food Safety Authority, advertising messages will not be allowed to be used unless they have a scientific cover. The products placed on the market must meet all the safety requirements, including appropriate labeling and necessary warnings on products. Consumers have right to obtain full and unbiased information about products and services, based on which they can make an appropriate decision about buying. Although there is the regulatory framework against deceptive marketing techniques, in practice the rights of costumers are not fully implemented. Because of this continued development of European legislation in the field of consumer protection is necessary.
\end{abstract}

Index Terms-Advertising, consumer protection, consumer rights, health claims, marketing techniques.

\section{INTRODUCTION}

Chocolates that stimulate growth, probiotic yogurts that strengthen immunity, cranberry products that help with urinary inflammation, the toothpaste which will make you irresistible - all these unchecked and fictional advertising promises are now officially prohibited. The European Union has decided to put an end to the false advertising, misleading consumers by promising them better health and appearance.

From 14 December 2014 applies new rule of European Food Safety Authority, according to which the manufacturers will be able to advertise healthy products only if they have their positive effect proven. Advertising messages such as "increases breasts", "reduces hair loss", "helps digestion", "enhance memory" will not be allowed to be used unless they have a scientific cover.

In 2006, health claims policy was published, and in mid-December 2014 ended the transfer window, after which advertising messages such as "iron contributes to the reduction of excessive hair loss" were not allowed. Manufacturers have to prove these and similar statements in front of the European Commission.

Manuscript received December 29, 2014; revised May 12, 2015. This work was supported in part by the Ministry of Science and Technology of Republic of Srpska.

The authors are with the University for Business Engineering and Management, Banja Luka, Bosnia and Herzegovina (e-mail: anakom09@gmail.com, keepsmiling_51000@yahoo.com).

\section{FUndAMENTAL CONSUMER RIGHTS}

At European Union level, the fundamental consumer rights are enshrined in Article 129 of the Treaty on Functioning of the EU. The products placed on the market must meet all the safety requirements, including appropriate labeling and necessary warnings on products. Consumers have right to obtain full and unbiased information about products and services, based on which they can make an appropriate decision about buying. The right to complaints and easier access to justice allow consumers to express dissatisfaction related to the purchased product or service provided.

The challenges faced by the common market, also apply to the digital revolution that has completely changed the way of presenting and selling products and services, organization and exchange of information in relation to simpler and quickly comparing prices and features of products.

On the other hand, the economic and financial crisis affected the economic power of consumers in a way that a large number of citizens is unable to provide for themselves and their families the basic goods and services, and consequently will not be able to use all the advantages of the digital market. Such sensitive consumers need to provide counseling and understanding of information, and to find the right products and services for their needs.

Today, consumers in the market are faced with rapid change and often are burdened with a large amount of information, which does not always include all the information that the consumer truly needs.

Consumer rights in Bosnia and Herzegovina, according to Law on Consumer Protection from 2006, are: the right of access to basic goods and services, the right to education on consumer issues, the right to safety and protection of life and health, right to be informed, right to have a choice, the right to be heard and represented, the right to be entitled to compensation for damages, and the right to live and work in a healthy and sustainable environment. According to Article 29 of mentioned Law, advertising of products and services must not be in conflict with laws and regulations and should not contain any statement or visible representation which would directly or indirectly by omission, incompleteness, or exaggeration mislead consumers, especially in regard to characteristics of the products or services such as: nature, composition, procedure and date of production, quantity, quality or geographical origin, the value of the product or service, delivery, exchange, return or maintenance, guarantee conditions, copyright and related rights. Advertising should not inappropriately use research results or quotations extracted from technical and scientific works. False advertising of products and services are considered to be 
advertising messages and actions by which consumers can be cheated or deceived, including the display with small letters, numbers, pictures and signs of essential components of offers, especially the price.

\section{Misleading AdVERTiSING AND NEGATIVE ClaimS}

Advertising messages have strong impact on our lives. The propaganda industry spends more than 480 billion dollars on commercials. Statistics show that children watch an average of 2.8 hours of television programming a day, and that adults watch an average of 4 hours a day. This means that during one year we watch 30769 commercials, and over a period of 65 years, the average person is going to watch more than 2 million commercials and this activity would take 2 years of our life. Expensive manipulative commercials aim to create longing for things and give us a promise that material things would bring us happiness and fulfillment. Previous practice indicated that in a variety of commercials only half matched the promises. In 2008 arrived 44.000 requires for advertising from manufacturers in the Member States. Out of that number EFSA scientifically tested 4600, and eventually obtained the license for 222 advertising messages.

Given the imminent application of the EU's Food Information Regulation, it is highly important to assure that consumers are not misled by astute marketing techniques that have no informative agendas, such as voluntary negative claims and clean labels (such as 'halal'). Negative claims can be defined as claims indicating that certain ingredients, nutrients or substances are not present in a food. Legitimate uses of regulated negative claims in the EU are some nutrition claims like "fat-free" and "gluten-free" claims. Negative claims may not be used with the aim to denigrate certain products in order to promote "free-from" products with the "hidden message" that whatever is used instead of the often "demonized" substance is safer, better, healthier or greener (e.g. Aspartame-free and palm oil-free).

\section{USE OF DIFFERENT MARKETING TECHNIQUES}

Metromedia Banjaluka, company for marketing and advertising and XYZ Clothing and Accessorize Department Store in Banjaluka enabled us to conduct the experiment related to buying behavior, which lasted for one month. Buyers/subjects were exposed to different marketing techniques such as: $\log$ o and commercials on billboards on main roads, different music and smells, bright colored or black and white decor. Results of the experiment, measured by surveys conducted among buyers after shopping, and also by keeping track of daily profit of the store, showed some interesting points. Our visual sense is not the most powerful in getting us interested to buy, because visual images are far more effective and memorable when they are coupled with another sense - like sound or smell. High percent of surveyed subjects agree that when a pleasant fragrance is matched by an appealing visual image, they perceived it as more pleasant and memorable. Most of subjects agreed that the feel of the product played an important role when they were deciding whether to buy it. Heavier items are perceived to be of higher quality. Colors were also very powerful tool in generating emotional connect to a brand, as the colored decor and the bright items increased brand recognition by up to $80 \%$, according to our results. Colored advertisements also held consumers attention much more than black and white ones. All in all, retail world use variety of different techniques like vivid colors, tunes and melodies to win customers attention and loyalty. Also, one of the highlighted points in our results was related to brand's logo. We concluded that logo is very important, especially nowadays when a closer look at some famous logos reveals subtle marketing tactics.

For example, the cleverness of the Amazon logo is twofold. The arrow points from A to Z, referring to all that is available on Amazon.com, and it doubles as a satisfied smile. The FedEx logo hides an arrow in its negative space. Even a glance subliminally inspires thoughts of efficiency and forward motion.

Vaio - This smart logo for Sony's computers represents the brand's integration of analog and digital technology. The 'VA' is designed as an analog waveform, the 'IO' is binary code.

Tour de France - Slightly more abstract than the other examples, the Tour de France logo contains a well-integrated biker.

Tostitos - The design within this logo conjures up feelings of togetherness and friendship over chips and salsa.

Coca-Cola - The soda brand's latest campaign in Denmark points out something you may have missed; the Danish flag (with a bulge) embedded in the white script.

LG - Some think the LG logo is a Pac-Man reference, but the smiling, winking face is more apparent.

Neuromarketing study conducted by Martin Lindstrom resulted in discovery that subliminal advertising is still being used by media in commercials and also by stores that play music containing concealed recorded messages prodding shoppers to buy more or not to shoplift. Subliminal messages include sounds, phrases and images that are being perceived by our subconscious mind below the level of conscious awareness. The human mind is divided in two parts, the conscious and the subconscious mind. The conscious mind works while we are awake and conscious. The subconscious on the other hand, is always activated, regulates everything in our body, our character, our speech, and receives and processes information, no matter what we do.

The subliminal messages technology exists for several decades. Many studies have shown that they can produce satisfying and lasting effects, from breaking unwanted habbits to improving performance. This technology is successful because offers the capability to interfere the "guard" of the subconscious mind, namely the analysis and processing of the logical, conscious mind.

The subconscious mind receives information for which we are not aware of and stores them.

\section{More Precise LABELING OF PRODUCTS FOR GREATER SAFETY OF CONSUMERS}

Directive on Consumer Rights 2011/83/EU from October 2011 substantially strengthened consumers` rights in the common market and created a framework for effectively combating unfair commercial practices, unfair contractual 
provisions as well as unauthorized advertising that led consumers to make decisions about buying or using services, which in some other objective situations would not bring. Due to exposure to the process of globalization, race for profits of both manufacturers and retailers became their main priority, so it is extremely important in such conditions to ensure effective policy of safety of products and services in a way that there are regulations aimed to prevent the availability of unsafe products and services to consumers.

The new rules of informing consumers about food products, which include the obligation of highlighting the nutritional and health information, provide additional high level of consumers' protection and give them the ability to make informed purchasing decisions. More precise food labeling for greater safety of consumers, stated in Regulation (EU) No. 1169/2011 on informing consumers about food, is required to be applied from December 14, 2014. Subject responsible for the information about the food is the one under whose name or business name the food is marketed, and there is a deadline of three years to fully adapt to the new rules.

Food placed on the market or labeled before 13 December 2014, which does not meet the requirements of the Regulation, may be sold until stocks are exhausted.

What should be stated? Mandatory labeling of nutritional values must include all the information specified below, and the amount of nutrients for which there is a nutrition claim or other substances for which there is a food or a health claim. The energy value and the amounts of fat, saturated fat, carbohydrates, sugar, protein and salt. The energy value should be expressed in kJ (kilojoules) and calories (kilocalories). First it is stated value in kilojoules, then the value in kilocalories. Abbreviation $\mathrm{kJ} / \mathrm{kcal}$ can be used.

What is the reference amount for the nutritional declaration? The amounts of nutrients are expressed in grams (g) per $100 \mathrm{~g}$ or $100 \mathrm{ml}$, and the energy value in kilojoules $(\mathrm{kJ})$ and kilocalories (kcal) per $100 \mathrm{~g}$ or $100 \mathrm{ml}$ of food.

In addition, it can be expressed per serving/unit consumption of food. Meal or units of consumption should be easily recognizable, quantified on the label in close near the nutrition declaration and the label must specify the number of meals and or units packaging contains. In addition, the energy value and amounts of fat, saturated fatty acids, carbohydrates, sugars, protein and salt can also be specified as a percentage of recommended intake per $100 \mathrm{~g}$ or $100 \mathrm{ml}$. In addition to or instead of such declaration to $100 \mathrm{ml}$ or 100 $\mathrm{g}$, the percentages of the recommended intake can be given as meal/unit of consumption. When the percentages of the recommended intake are stated per $100 \mathrm{~g}$ or $100 \mathrm{ml}$, nutritional declaration contains the following statement "the recommended intake for an average adult (8 $400 \mathrm{~kJ} / 2000$ kcal)".

The new rules provide consumers with clear, comprehensive and accurate information about content of food and help them make informed decisions about what they eat. Key changes in food labeling are improved readability of information (minimum font size for mandatory information); clear and coherent listing of allergens in the list of ingredients (eg soy, nuts, gluten, lactose) in previously packaged foods; mandatory information about allergens for non-packaged foods, including food in restaurants and cafes; request for specific information of nutrition for most packaged processed foods; compulsory information on the origin of fresh meat of pigs, sheep, goats and poultry; a list of modified nanomaterials in ingredients; specific information on the plant origin of refined oils and fats and reinforced rules in order to prevent misleading practices of traders.

\section{POSITION OF CONSUMERS ON THE INTERNAL MARKETS AND EXERCISING CONSUMER RIGHTS}

The Consumer protection is an important segment of the internal market. The fact that the consumer is the weaker party in the market, and that the retailer has more knowledge and information about the products that are being sold compared to consumer who buys them may lead to an imbalance in the market to the detriment of consumers. The term Consumer protection is broad and includes both protection against deceptive advertising and unfair marketing plans, and also product safety regulations and juridical solution in consumer disputes.

Even developed countries like USA have problems with the violation of consumer rights, but they have better mechanisms of protection and the greater opportunities to react quickly when there is an issue on the market. The proof is successful class action complaint filed by misled customers against Red Bull.

The Austrian drinks giant agreed to a \$13 million settlement with American consumers after a lawsuit challenged the energy drink's claim to "give you wings" in a class action complaint that alleged the distinctive-tasting drink was no more effective than a cup of coffee despite advertisement that promised increased performance and concentration. No proof of purchase is required for claims.

It was not immediately clear how the total payout sum would be divided among the millions of annual consumers of the caffeinated drink.

The settlement, approved by the U.S. District Court of the Southern District of New York, (1) Benjamin Careathers $v$. Red Bull North America, Inc., Case No. 1:13-CV-00369 (KPF); and (2) Wolf et al. v. Red Bull GmbH, et al,. Case No. 1:13-CV-08008 (KPF), offers any consumer who bought a Red Bull between Jan. 1, 2002, and Oct. 3, 2014, either \$10 cash or $\$ 15$ worth of Red Bull products. It has since been confirmed that the amount refunded to individuals could be much lower than originally estimated, as more and more consumers apply for compensation from a finite pool of settlement money.The law firm said complainant Benjamin Careathers alleged Red Bull was "misleading customers" by making claims about the "functional beverage" and its ability to "give you wings" despite reports concluding energy drinks had the same benefit as he the average dose of caffeine consumed in coffee. The class-action lawsuit, which began in January 2013, cited evidence in The New York Times, Nutrition Reviews and the European Food Safety Authority Journal that indicated energy drinks provide their boost through caffeine alone, not guarana or any other ingredient. According to the complainant, the Austria-based firm deliberately misled unsuspecting customers to spend millions of pounds on the premium drink in the hope of gaining an 
edge on their competitors. Red Bull said it had settled the lawsuit to "avoid the cost and distraction of litigation" and maintains that its marketing has "always been truthful and accurate."

\section{CONCLUSION}

It is considered that the policy of consumer protection within the common market represents significant contribution to sustainable development of Europe by 2020. This is only possible if consumers feel safe and have built confidence in the common market in the sense that it would be easier and quicker to exercise their consumer rights. To empower consumers means to provide them with proper regulatory framework and effective tools that will enable them to make informed and responsible decisions about buying products and services. It is necessary to educate them on how to exercise their rights and to protect them against deceptive advertising and unfair marketing plans. Although there is the legislation against deceiving marketing and false advertising, the rights of costumers are not respected, since in the media there is a large number of seducing commercials and subliminal techniques used to manipulate consumers, along with exploitive marketing tactics. Because of this continued development of European legislation in the field of consumer protection is necessary, along with the harmonization of regulations in Bosnia and Herzegovina with European regulations.

\section{REFERENCES}

[1] E. Taylor, "Subliminal information theory revisited: Casting light on a controversy," Annals of the American Psychotherapy Association, 2007.

[2] C. V. Agostoni, "EFSA panel on dietetic products, nutrition and allergies (NDA)," EFSA Journal, vol. 7, no. 9, p. 1260, 2009.

[3] 1. Loudon, D. Bella, and B. J. A, Consumer Behavior, Concepts and Allocations, $4^{\text {th }}$ ed., McGraw-Hill, Inc., 1993.

[4] A. Ivanovic and P. Collin, Dictionary of Marketing, $3^{\text {rd }}$ ed., London: Bloomsbury Publishing co, 2003.

[5] M. Lindstrom, "Buy ology: Truth and lies about why we buy," 2008.
[6] J. Murphy, The Power of Your Subconscious Mind, Wilder Publications, 2008.

[7] Voluntary Non-GMO/GMO-Free Labeling claims, Regulatory developments in European member States, in Proc. the 2nd International Non-GMO Soy summit, Brussels, October, 2008.

[8] Report on Consumer Policy, European Commission, January 2012 December 2013.

[9] Directive on Consumer Rights, 2011/83/EU, October 2011.

[10] EU's Food Information Regulation, EU Regulation 1169, 2011.

[11] Official gazette of Bosnia and Herzegovina, Law on Consumer Protection, April, 2006.

[12] EU Food Law. [Online]. Available: http://www.eurofoodlaw.com/health-claims/briefing-how-legal-are-ne gative-claims-such-as-bpa-free-or-aspartame-free-104476.htm

[13] The Curious Case of Russia Within WTO - CNN iReport. [Online]. Available: http://www.eurofoodlaw.com/health-claims/

[14] European food added. [Online]. Available: http://www.efsa.europa.eu/

[15] Timeentrynet. [Online]. Available: http://www.ozp.gov.ba/

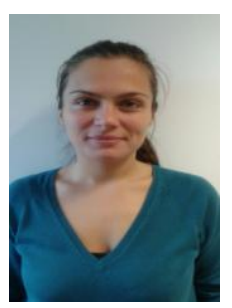

Ana Komljenovic was born in Banja Luka, Republic of Srpska, Bosnia and Herzegovina, in 1986. she was graduated from Faculty of Law in Bosnia and Herzegovina in 2011, and she received her master degree of international law in 2012.

She works in Ministry of Education and Culture of Republic of Srpska, Bosnia and Herzegovina. Her research interests are in international law, european union, social science. M.Sc. Komljenovic is a member of MENSA and a member of CRIS (current research information system) of republic of Srpska.

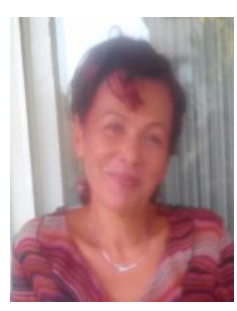

Brana Komljenovic was born in Prijedor, in former Yugoslavia, in 1956. She was graduated from Faculty of Law in Banja Luka in 1979, and became a magister of law in 2003 in Belgrade, Republic of Serbia, and a doctor of law science in 2008, at the University of Banja Luka, in Banja Luka, Bosnia and Herzegovina. She worked as the secretary of University in Banjaluka. After becoming a professor, she worked at University of Business Studies, and now she is a teacher in University of Business Engineering and Management in Banja Luka, Bosnia and Herzegovina. Her research interests are in business law, international law, European union, united nations.

Dr. Sc. Komljenovic is a member of CRIS (current research information system) of Republic of Srpska. 